\title{
STAGING AND AGEING OF MAMMALIAN EMBRYOS AND FETUSES
}

\section{O. ŠTĚRBA}

Department of Anatomy, Histology and Embryology, Faculty of Veterinary Medicine, University of Veterinary and Pharmaceutical Sciences, 61242 Brno

Received September 22, 1994

Accepted March 30, 1995

\begin{abstract}
Š t e r $\mathrm{b}$ a O.: Staging and Ageing of Mammalian Embryos and Fetuses. Acta vet. Brno, 1995, 64: 83-89.

The objective of this study was to elaborate a method of estimating the age of embryos and fetuses of mammals of unknown ontogenetic age, applicable to both altricial and precocial mammals showing different duration of intrauterine development. The method consists of two steps: First, the embryo or fetus under study has to be "staged". It is measured, weighed and classified according to the characteristics given below, in one of the 13 comparable ontogenetic stages. The second step is "ageing": the staged embryo is placed in a point on the regression curve of the respective developmental stage that corresponds to the duration of intrauterine development. The characteristics of the comparable developmental stages, the regression curves and the way in which they are calculated are presented. This method makes it possible to estimate the age of mammalian embryos and fetuses of unknown ontogenetic age, even of those already sectioned in histological series. In this way it is also possible to estimate the rates of morphogenetic events, the growth rate of the whole embryo or of its individual parts and/or organs.
\end{abstract}

Ageing, embryos, fetuses, comparable developmental stages, mammals, staging, regression age curves

In comparative studies of the embryonic development of mammals, one is often compelled to use material of embryos and fetuses of unknown copulation or gestation age. This situation is almost regular in the case of free-living mammals, often inhabiting such hardly accessible environments as water or underground spaces, and also reproducing in seclusion. Such mammals will rarely or never reproduce in captivity. Thus, the embryonic material of such mammals is usually not dated, often incomplete and very rare. The hope that it may be completed is dwindling due to fact that the number of protected mammalian species is ever-increasing, and the possibility of obtaining such material is practically non-existent. The items of knowledge obtained from un-aged material remain on a descriptive level, their explanatory and predictive value being low and the resulting effect being disproportional to the effort expended. In such cases, it is difficult, to visualise the time course and duration of the successive ontogenetic events, and the time relations between them are hard to find. One cannot even estimate whether a particular ontogenetic event procceds at the usual rate or whether it is retarded or accelerated, or whether its onset has not been shifted to an earlier or later time span. Having encountered these difficulties myself, I have tried to elaborate a method by which to determine the ontogenetic age of mammalian embryos and fetuses without knowing the moment of fertilization.

First of all, it was necessary to establish criteria that would make it possible to compare embryos of different species of mammals. Mammals are known to range in size from small shrews up to the elephant or the blue whale, with the duration of their intrauterine development varying in length from 16 days in the golden hamster up to 15 - 17 months in the rhinoceros or the cachalot. Also, the newborns differ in the degree of development, from naked, blind ones almost incapable of movement (as in shrews or mice) up to those, covered with developed hair coat, functional eyes and capable of following their mother and herd shortly after birth (as in ungulates). Therefore it was first necessary to select, in the embryos and fetuses, such characters that occur 
in all mammalian species and by means of which one could determine one and the same degree of morphogenetic development. For this purpose, I have used the so-called "staging".

Ontogeny is generally viewed as an uninterrupted flow of developmental changes, comprising an infinite number of stages, the latter representing arbitrary cross-sections through their life on the time-coordinate (de B e e r 1958). For practical use only a certain number of stages has been selected, each of them being characterized by the degree of morphological differentiation of several organs in a group of embryos of approximately equal size and equal ontogenetic age. Thus, a stage is not determined by age or size alone, there being a certain variation range as well as individual variation. The system of stages, expressing the average state of mutually conditioned dvelopmental events, permitted looking for mutually comparable stages in embryos and fetuses of different species, regardless of the size of the animal or the duration of its intrauterine development. Such stages had already been established in several mammalian species.

In the embryonic development of man, $M$ a 11 (1914) established 21 stages; later, $S \mathrm{t} r$ e e t e r $(1942,1945,1948,1951)$ increased their number to 23 and called them "developmental horizons". The term "stage" was re-used by O'R a h i 11 y (1973) who called this system "the Carnegie system of stages". The Carnegie system was then used to stage embryos of additional primates by $\mathrm{H} \mathrm{e} \mathrm{n} \mathrm{d} \mathrm{r} \mathrm{i} \mathrm{c} \mathrm{k} \mathrm{x} \mathrm{(1971)} \mathrm{in} \mathrm{the} \mathrm{embryonic}$ development of baboon, Papio cynocephalus; by $\mathrm{P} \mathrm{h}$ i 11 i p s (1976) in the marmoset, Callithrix jacchus; and by G r i b n a u and G e i j s b e r t s (1981) in Rhesus monkey, Macaca mulatta. G r i b n a u and $\mathrm{G}$ e i j s b e r t s (l.c.) believed the Carnegie system of stages to be generally applicable, and they attempted to apply it to the prenatal development of rodents used in experimental medicine. However, these rodents show a much shorter duration of intrauterine development and the stages of the Carnegie system follow one another at very short time intervals so that they overlap, particulary during the second part of the gestation period.

Subsequent authors divided the ontogeny of mammals used largely for experimental purposes into stages according to similar characteristics as those used in the Carnegie system for the embryos of man and some primates. However, among those stages were even those characteristics of only some species, and included even the part of the fetal period until birth. Thus, for example, T h e i 1 e r (1972) established 27 stages in the prenatal development of the laboratory mouse; D y b a $\mathrm{n}$ et al. (1975), 24 stages in the prenatal development of the laboratory mouse, laboratory rat, the Chinese hamster, Cricetulus griseus, and the domestic rabbit, Oryctolagus cuniculus; and t e n D o n k e l a a r et al. (1979), 22 stages in the prenatal development of Chinese hamster, Cricetulus griseus.

I found the different numbers of stages to be disadvantageous for comparative studies. Therefore, I have developed my own system of stages that are comparable with some of the stages in the systems mentioned above.

\section{Materials and Methods}

For comparable ontogenetic stages, I have selected and defined 13 stages that are comparable with the above-mentioned stage systems. My stages $1-6$ cover the embryonic period, stages $7-13$ the fetal one. The last stage (13) is that of the newborn. In mammals, this stage either follows stage 7 (e.g. in Sorex araneus, Neomys fodiens; see $\zeta \mathrm{t} t \mathrm{r}$ b a 1977a), or stages 9 and 10 (the majority of rodents of the families Muridae and Arvicolidae; see $S \mathrm{t}$ ¿ $\mathrm{r}$ b a 1976, 1977b) or stage 11 (e.g. such carnivores as Felis catus, or altricial lagomorphs - Oryctolagus cuniculus; see $\mathrm{S} t \mathrm{e}$ r b a 1978), or only after stage 12 has been attained (all precocial mammals, e.g. artiodactyls; see $\zeta \mathrm{t}$ e $\mathrm{r}$ b a 1979). Thus there is no uniform mammalian newborn ( $S$ t e r b a 1984). The following synopsis presents the morphological characteristics of the successive stages. 


\begin{tabular}{cl}
$\begin{array}{c}\text { Number } \\
\text { of stage }\end{array}$ & Characteristics of stage \\
\hline 1 & Primitive streak \\
2 & First somites (1-7) \\
3 & $\begin{array}{l}\text { Four branchial bars, limb buds, tail bud, otic vesicle closed, lens plate indented, olfactory } \\
\text { placode indented, cerebral vesicles distinct } \\
\text { Retinal pigment present, lens vesicle closed and separated from surface, hemispheres } \\
\text { and mesencephalon conspicuous, handplate present }\end{array}$ \\
4 & $\begin{array}{l}\text { Porus acusticus externus formed, follicles of tactile hairs present on upper lip, lens cavity } \\
\text { reduced or obliterated, nasolacrimal groove closed, palatine processes vertical, handplate }\end{array}$ \\
5 & indented \\
6 & Palate fused, eyelids are prominent, toes separated, ossification begins \\
7 & Fusion of eyelids, umbilical hernia reposited \\
8 & Numerous skinfolds present \\
9 & Tactile hairs erupt on upper lip \\
10 & First fine hairs on body \\
11 & Body covered with dense and long hairs \\
12 & Eyelids separated \\
13 & Newborn
\end{tabular}

Comparable ontogenetic stages are compared with other stage systems in the following synopsis:

\begin{tabular}{|c|c|c|c|c|c|}
\hline $\begin{array}{c}\text { Comparable } \\
\text { ontogenetic } \\
\text { stages }\end{array}$ & $\begin{array}{l}\text { Carnegie } \\
\text { system of } \\
\text { stages }\end{array}$ & $\begin{array}{c}\text { Gribnau \& } \\
\text { Geijsberts } \\
\text { (1981) }\end{array}$ & $\begin{array}{l}\text { Theiler } \\
\text { (1973) }\end{array}$ & $\begin{array}{l}\text { Dyban } \\
\& \text { al. } \\
(1975)\end{array}$ & $\begin{array}{l}\text { tenDonkelaar } \\
\& \text { al. } \\
(1979)\end{array}$ \\
\hline 1 & 6 & 6 & 9 & 8 & - \\
\hline 2 & 9 & 9 & 12 & 11 & 9 \\
\hline 3 & 13 & 13 & 16 & 14 & 13 \\
\hline 4 & 16 & 16 & 19 & 15 & 16 \\
\hline 5 & 19 & 19 & 21 & $17-18$ & 18 \\
\hline 6 & 23 & 23 & 23 & 19 & 19 \\
\hline 7 & - & - & 24 & 22 & F2 \\
\hline 8 & - & - & 25 & - & F2 \\
\hline 9 & - & - & 26 & 23 & F3 \\
\hline 10 & - & - & - & 24 & - \\
\hline 11 & - & - & - & - & - \\
\hline 12 & - & - & - & - & - \\
\hline 13 (Newborn) & - & - & 27 & 23 & F3 \\
\hline
\end{tabular}

The next step was to construct the time course of ontogeny: I attempted to determine the ontogenetic age of staged embryos and fetuses. For that purpose, I selected 10 mammalian species showing different duration of intrauterine development, different newborn stage and different size at birth, for which the time course of ontogeny had been described in the literature. The ten species are listed below:

\begin{tabular}{lccc} 
Species & $\begin{array}{c}\text { Duration of } \\
\text { gestation/days }\end{array}$ & $\begin{array}{c}\text { CRL at } \\
\text { birth/mm }\end{array}$ & Abbrev. \\
\hline Mesocricetus auratus & 16 & 24 & Mea \\
Laboratory mouse & 19 & 25 & $\mathrm{Lm}$ \\
Microtus arvalis & 21 & 28 & Ma \\
Oryctolagus cuniculus & 30 & 95 & Oc \\
Acomys dimidiatus & 38 & 36 & $A d$ \\
Felis catus & 60 & 130 & $F c$ \\
Cavia aperea var. porcellus & 68 & 100 & $C p$ \\
Sus domesticus & 114 & 280 & $S d$ \\
Ovis aries & 150 & 500 & Oa \\
Bos taurus & 280 & 850 & $B t$ \\
Equus caballus & 335 & 1000 & $E c$ \\
\hline
\end{tabular}


On the basis of published criteria, I classified the embryos and fetuses into the 13 comparable ontogenetic stages (Mesocricetus auratus: B o y e r 1953; laboratory mouse: T h e i l e r 1972; Microtus arvalis: $S$ t e r b a 1976; Oryctolagus cuniculus: M i n ot and T a y lor 1905; Acomys dimidiatus: Die ter $\mathrm{l}$ e $1963 ;$ Felis catus: $\mathrm{E} v$ a $\mathrm{n}$ s and S a c k 1973, S t è r b a 1978; Cavia porcellus: S c o t t 1937, R a j t o vá 1972; Sus domestica: K e i b e 1 1897, M a r r a b l e 1971, E v a n s and S a c k 1973; Ovis aries: B r y d e n et al. 1972; Bos taurus: B e r g m a n n 1922, B ung er 1972, Ev a n s and S a ck 1973; Equus caballus: B a r one and L a pl a ce 1965, Ev an s and S a ck 1973).

For the above staged embryos and fetuses, I calculated the percentages of the gestation period at which they attain stages $1-9$, as shown in the following review. In these species, whose gestation period lasts from 16 to 335 days, the duration of the gestation period was taken as $100 \%$.

Stage in $\%$ of the duration of gestation

\begin{tabular}{rrrrrrrrrrrr}
\hline 9 & 96 & 94 & 90 & 80 & 75 & 62 & 57 & 48 & 44 & 35 & 32 \\
8 & 90 & 87 & 84 & 75 & 70 & 56 & 52 & 38 & 34 & 27 & 24 \\
7 & 85 & 82 & 78 & 70 & 63 & 50 & 46 & 34 & 30 & 22 & 20 \\
6 & 82 & 76 & 73 & 63 & 56 & 44 & 38 & 28 & 26 & 19 & 16 \\
5 & 72 & 67 & 64 & 54 & 49 & 37 & 33 & 24 & 22 & 15 & 12 \\
4 & 64 & 61 & 57 & 48 & 44 & 32 & 28 & 18 & 17 & 12 & 9 \\
3 & 56 & 52 & 50 & 42 & 39 & 28 & 26 & 16 & 13 & 9 & 7 \\
2 & 44 & 42 & 40 & 35 & 31 & 25 & 21 & 13 & 10 & 7 & 5 \\
1 & 38 & 36 & 34 & 30 & 26 & 20 & 16 & 9 & 7 & 6 & 4 \\
\hline Species & Mea & Lm & Ma & Oc & Ad & Fc & Cp & Sd & Oa & Bt & Ec
\end{tabular}

From the percentages, I calculated the polynomial regression variances of the 3rd to 5th degree. In graphic representation, these regression variances gave regression age curves. The curves show at which percentages of the duration of intrauterine life the mammalian species showing different gestation periods will attain a particular stage (Fig. 1).

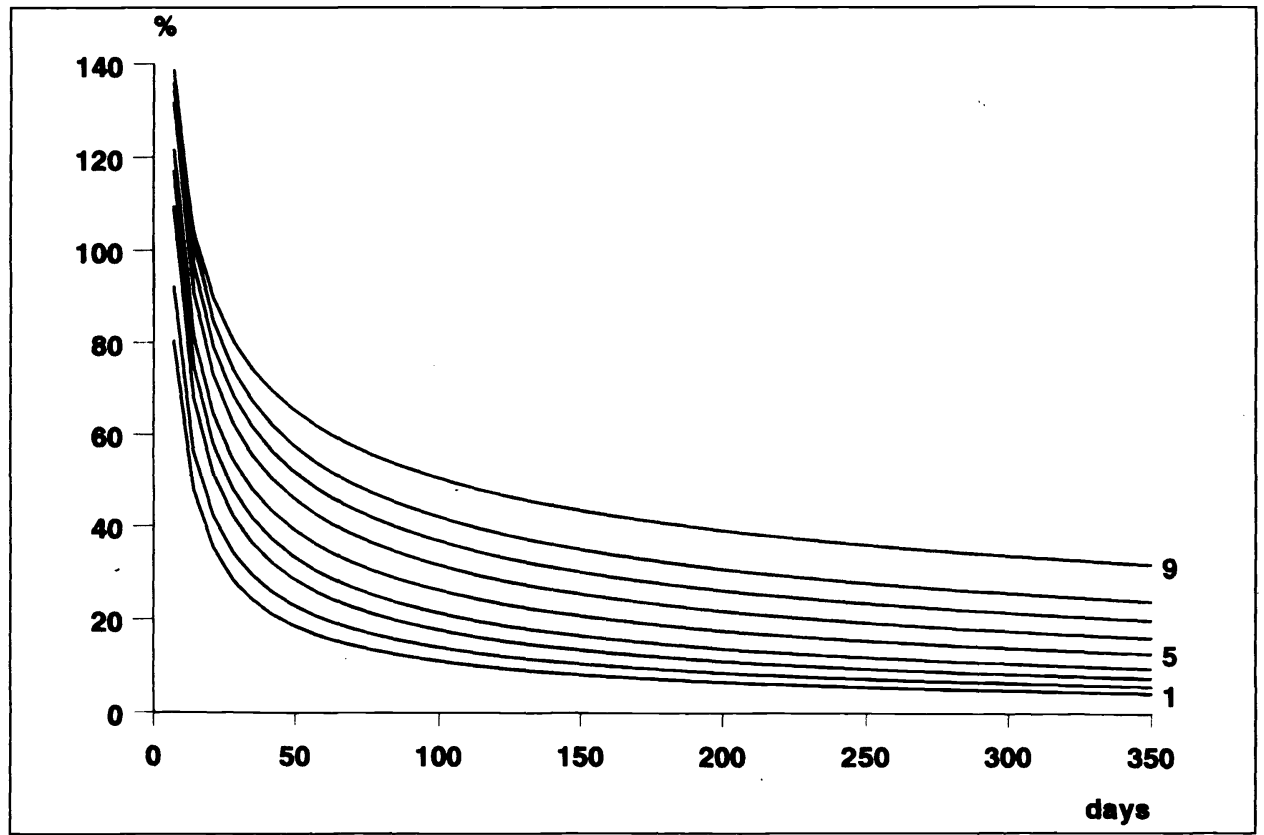

Fig. 1. Abscissa: duration of prenatal development in days. Ordinate: percentage duration of prenatal development. The curves connect the successive ontogenetic stages $1-9$, beginning with the bottom one for stage 1. Example of use: Knowing that the intrauterine development of the mammal under study lasts 100 days, a line is uprighted in that point on the abscissa. The intersections of that line with the regression curves indicate the percentages of the duration of intrauterine development at which the embryo will attain ontogenetic stages 1 - 9. The diagram is valid for mammal species with gestation period lasting 16 - 335 days. 


\section{Results}

The following is the working procedure: First, it is necessary to carry out morphological classification of the embryo or fetus under study. This step is called the "staging" and it must be carried out in the first place. Thus, the embryos and fetuses available are collected and classified by their external morphological characteristics into the respective stages. At the same time, their crown-rump lengths (CRL) and additional (even partial) dimensions are measured, and their weight $(\mathrm{W})$ is determined. The more dimensions are obtained, the more detailed the study will be, as it is then possible to follow in greater detail the proportional growth and its rates by means of allometric and allochronic calculations.

The next step is the "ageing" of the embryos and fetuses. From the age regression curves are read the relative ages of the embryos in stages $1-9$. This is done as follows: On the abscissa, showing absolute values of the duration of intrauterine cdevelopment in days (from 16 to 335 days), the point is found that corresponds to the duration of intrauterine development of the mammalian species in question. A line uprighted from that point will intersect the regression curves. The intersections then indicate the percentages of the relative duration of intrauterine development at which the embryo will attain ontogenetic stages $1-9$. The regression age curves show the dependence of the occurence of the ontogenetic stages upon time. The longer the intrauterine period, the more is the embryonic development shifted to the relatively earlier stages of gestation.

\section{Discussion}

The Staging and Ageing Method has already been tested on several groups and species of terrestrial and marine mammals: Insectivora ( $\check{S} \mathrm{t} \check{\mathrm{r}} \mathrm{r}$ a 1975, 1977a), Rodentia ( $\breve{S} \mathrm{t} \check{\mathrm{r}} \mathrm{r}$ b a 1976, 1977b), Castor spp. (P i 11 e r i et al. 1985), Lagomorpha (Š t ě r b a 1978, 1981), Arti-

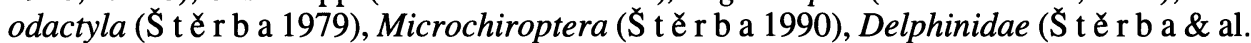
in press). Applied to embryonic stages, the staging system has been found fully satisfactory for all species and all groups. During that period, the embryos do not differ much in size or appearance (e.g. the mean CRL of the mole embryo in stage 3 is $3.8 \mathrm{~mm}$, the CRL of the horse embryo in the same stage is $6.5 \mathrm{~mm}$; the CRL of embryonic mole in stage 6 is $13.5 \mathrm{~mm}$, that of the embryonic horse in the same stage is $23 \mathrm{~mm}$ ). The method also clarifies the dependence of ontogenetic stages upon time. The longer the intrauterine period, the more is the embryonic development shifted to the relatively earlier periods of gestation. Thus, in rodents with 19 - 22 days of gestation, the embryo will attain stage 3 on the 10th - 12th day of gestation ( $\check{S} \mathrm{t} \check{\mathrm{r}} \mathrm{b}$ a 1976, 1077b). In the domestic pig with 114 days of gestation, the embryo will attain stage 3 in 17 days ( $\ \mathrm{t} \check{\mathrm{r}} \mathrm{b}$ a 1979), and in the horse with 335 days of gestation, in 23 days ( $\mathrm{S} \mathrm{t} \check{\mathrm{r}} \mathrm{b}$ a 1983). Since mammalian embryos are small in size at first and the morphogenetic events take place in small spaces and short distances, they are controlled by epigenetic mechanisms (W a d d i n g t o $\mathrm{n} 1968$; $\mathrm{L} \varnothing \mathrm{v} \mathrm{tr}$ u p 1974). In this period are realized the characters of such higher taxa as the phylum, subphylum, superclass and class. The first signs of future limb specializations are already apparent at the beginning of stage 4. Hence, limb adaptations and specializations are proper to the classes amphibians, reptiles, birds and mammals, and thus their superordinate taxon, the superclass Tetrapoda, is justified from the point of view of the natural system. The diaphragm, a character of the class Mammalia, is observed also in stage 4. The characters of orders and families become manifest in stage 5 and 6 . Here it has become apparent, that the definitions of some character are not universally applicable. One of the characters used to define stage 5 , the rudimentary pinna, does not occur in all mammalian groups. In dolphins, in which group there is no pinna not even the rudiments of this organ are formed. It will be better if this character is defined 
as the formation of a meatus and porus acusticus externus. Similarly, no general use can be ascribed to another character -follicles of body hairs- which regularly occurs in embryonic altricial mammals in stage 6 but does not occur in precocial ones until fetuses in stage 8. In dolphins, in which no body hairs are found, this character cannot occur at all. Therefore in dolphins, we had to replace the characters of stage 10 -first fine hairs on body- and of stage 11 - body covered with dense and long hairs- by differentiating the amount of pigment present in skin, causing the brown (in stage 10) and black (in stage 11) skin coloration. One may state in general that allochronic shifts are very often observed in the course of ontogeny of skin and skin derivates. In that period, allochronic shifts must be expected to occur even in other organ systems. Changes in shape and dimensions, indicating individualization of the embryo, are the most conspicuous and externally visible events in the fetal and juvenile period, the development being controlled by mechanisms of qualitative differential and quantitative allometric growth ( $\mathrm{H} \mathrm{u}$ x l e y 1932).

The characteristics of fetal stages, mainly the 10th, 11th, and 12th ones, have been based on characters subject to allochronic shifts. Therefore, it will be necessary to supplement them by size and weight data allowing better deductions of the time relations (cf. $\mathrm{N}$ e.w $\mathrm{m}$ a $\mathrm{n}$ and $\mathrm{H}$ e $\mathrm{n} \mathrm{d} \mathrm{r} \mathrm{i} \mathrm{c} \mathrm{k} \mathrm{x} \mathrm{1984).} \mathrm{For} \mathrm{this} \mathrm{reason,} \mathrm{the} \mathrm{time} \mathrm{occurrence} \mathrm{of} \mathrm{these} \mathrm{stages} \mathrm{has} \mathrm{not} \mathrm{been}$ included in the calculations of regression curves.

\section{Stanovování ontogenetického věku embryí a plodů savců}

V práci je popsána pủvodní metoda "Staging and ageing" embryí a fétů savců a je uveden návod $\mathrm{k}$ jejímu použití. Nejprve je nutno zárodek změřit, zvážit a zařadit podle uvedených charakteristik do príslušného stadia a pak určit věk podle umístění stadia na regresní věkové křivce. Charakteristiky srovnatelných vývojových stadií a regresní křivky jsou připojeny. Metoda umožňuje stanovení věku embryí a plodů savců neznámého ontogenetického stárí. Možno použít také u embryí již nakrájených do histologických serií. Je také možno určit rychlost rủstu celého zárodku, jeho cástí a jednotlivých orgánů.

\section{References}

BARONE R., LAPLACE J.P. 1965: En embryon de jument de 12.5 mm. Rev. Méd. Vét. 116:761-786 deBEER G.R. 1958: Embryos and ancestors, 3rd Edit., Oxford University Press, London

BERGMANN R. 1922: Beiträge zur Alterbestimmung von Kalbföten der schwarzbunten Niederungsrasse. Arch. Tierheilk. 47: 292-315

BOYER C. 1953: Chronology of development for golden hamster. J. Morph. 92: 1-33

BRYDEN M.M., HOWARD E., BINNS E.W.1972: Embryology of the sheep. I. Extraembryonic membranes and the development of body form. J. Morph. 138: 169-186

BÜNGER I. 1972 : Beitrag zur Alterbestimmung von Feten des deutschen schwarzbunten Rindes insbesondere auf Grund von Längemessungen. Thesis, Tierärztl. Hochschule, Hannover

DIETERLEN F. 1963: Vergleichende Untersuchungen zur Ontogenese von Stachelmaus (Acomys) und Wanderratte (Rattus norvegicus)- Beiträge zum Nesthocker-Nestflüchter-Problem bei Nagetieren. Z. Säugetierkunde 28: $193-227$

DONKELAAR ten H.J., GEIJSBERTS L.G.M., DEDEREN P.J.W. 1979: Stages in the prenatal development of the Chinese hamster (Cricetulus griseus). Anat. Embryol. 156: -28

DYBAN A.P., PUCHKOV V.F., BARANOV V.S., SAMOSHKINA N.A., CHEBOTAR N.A. 1975 : Laboratory mammals. In: Objects of developmental biology (In Russian). Nauka, Moscow

EVANS H.E., SACK W.O. 1973: Prenatal development of domestic and laboratory mammals. Anat. Histol. Embryol. 2:11-45

GRIBNAU A. A. M., GEIJSBERTS, L.G.M. 1981 : Developmental stages in the Rhesus monkey (Macaca mulatta). Advances in Anatomy, Embryology and Cell Biology 68:1-84. Springer, Berlin, Heidelberg, New York

HENDRICKX A.G. 1971 : Embryology of the baboon. University of Chicago Press, Chicago

HUXLEY J.S. 1932: Problems of relative growth. Methuen \& Co, London

KEIBEL F. 1897: Normentafel zur Entwicklungsgeschichte des Schweines (Sus scrofa dom. L.). G. Fischer, Jena

L $\varnothing$ VTRUP S. 1974: Epigenetics. A treatise on theoretical biology. J. Wiley \& Sons, London, New York, Sydney, Toronto. 
MALL F.P. 1914: On stages in the development of human embryos from 2 to $25 \mathrm{~mm}$ long. Anat. Anz. $46: 74-84$

MARRABLE A.W. 1971: The embryonic pig, a chronological account. Pitman Medical, London

MINOT C.S., TAYLOR E. 1905: Normal Plates of the development of rabbit (Lepus cuniculus L.). Vol. 5 of Keibel's Normentafeln G. Fischer, Jena,

NEWMAN L.M., HENDRICKX A.G. 1984: Fetal development in the normal thick-tailed bushbaby (Galago crassicaudatus panganiensis). Am. J. Primatol. 6:337-355

O'RAHILLY R. 1972: Guide to the staging of human embryos. Anat. Anz. 130:556-559

PHILLIPS I.R. 1976: The embryology of the common marmoset (Callithrix jacchus). Advances in Anatomy, Embryology and Cell Biology, 52 .

PILLERI G., KRAUS C., GIHR M. 1985: Ontogenesis of Castor canadensis in comparison with Castor fiber and other rodents. In: Pilleri, G.(ed): Investigations on beavers, Vol. 4:11-96, Berne.

RAJTOVÁ V.1972: Morphogenesis des Chondrocranium beim Meerschweinchen (Cavia porcellus L.). Anat. Anz. 130:176-202

SCOTT J.P. 1937: The embryology of the guinea pig. I. A table of normal development. Am. J. Anat. 60:397-432

STREETER G.L. 1942 : Developmental horizons in human embryos. Age groups XI, XII. Contr. Embryol. Carneg. Instn. 30:211-245

STREETER G.L. 1945 : Developmental horizons in human embryos. Age groups XIII, XIV. Contr. Embryol. Carneg. Instn., 31:27-63

STREETER G.L.1948 : Developmental horizons in human embryos. Age groups XV, XVI, XVII, XVIII. Contr. Embryol. Carneg. Instn. 32: 133-203

STREETER G.L. 1951: Developmental horizons in human embryos. Age groups XIX, XX, XXI, XXII, XXIII. Prepared for publication by C.H. Heuser and G.W. Corner. Contr. Embryol. Carneg. Instn. 34:165-196

ŚTÉRBA O. 1975: Prenatal growth of the mole, Talpa europaea Linn., 1758. Folia morphol. Praha 23:282-286

STEKRBA O. 1976 : Prenatal development of microtine rodents. Acta Sc. Nat. Brno 10 (1):1-41

ŚTĚRBA O. 1977a : Prenatal development of Central European insectivores. Folia Zool. 26: 27-44

ŚTĚRBA O. 1977b: Prenatal development of selected altricial and precocial rodents. Acta Sc. Nat. Brno 11 (11): 1-36

ŠTĚRBA O. 1978: Prenatal growth and development of Oryctolagus cuniculus and Felis catus. Folia Zool. 27: $1-12$

ŠTĚRBA O. 1979: Prenatal growth of certain artiodactyls. Fol. Zool. 28:321-328

STĚRBA O. 1981: Prenatal development and growth of Lepus europaeus. Fol. Zool. 30:147-154

ŚTĚRBA O. 1983: : Prenatal growth and development of model mammal species. (In Czech). Thesis ISEB CAS Brno, 264 p.

ŠTĚRBA O. 1984: Ontogenetic patterns and reproductive strategies in mammals. Föl. Zool. 33:65-72

ŠTĚRBA O. 1990: Prenatal development of Myotis myotis and Miniopterus schreibersi. Fol. Zool. 39:73-83

STĚRBA O., KLIMA M., SCHILDGER B. : Staging and ageing of embryos and fetuses of Stenella attenuata, $S$. longirostris, Delphinus delphis and Phocoena phocoena. (In press).

THEILER K. 1972: The house mouse. Development and normal stages from fertilization to 4 weeks of age. Springer, Berlin, Heidelberg, New York 